\title{
Pengaruh Laba Bersih Terhadap Dividen Kas Pada Perusahaan PT. Indofood CBT Sukses Makmur Tbk
}

\author{
Herman \\ Akuntansi Perpajakan, Ekonomi dan Bisnis, Politeknik Baubau, Baubau, Indonesia \\ hermanalhshak@gmail.com
}

\begin{abstract}
Among the main sources of companies to decide on dividend payments to investors was profit, management also considers whether to retain profits (not distributed to investors) for the purpose of purchasing fixed assets in order to improve company operations which have an impact on the company's ability to generate profits. This study takes data on net income and cash dividends of PT. Indofood CBT Sukses Makmur Tbk for seven years, starting from 2014 to 2020. This research is a quantitative research that is classified as parametric statistical inferential research, examines the effect, including the associative hypothesis, uses ratio data, which is the highest type of data in the study, then uses one independent variable. and one dependent variable, so that the analytical tool used is simple regression analysis. The results showed that there was a positive and significant influence between net income and cash dividends at PT Indofood CBP Sukses Makmur Tbk. This can be seen in the significance value of $0.02<0.05$ and the $T$ count of $5.773>$ the $T$ table value of 2.570 .
\end{abstract}

Keywords: Profit, Dividend, Investors

\begin{abstract}
Abstrak
Diantara sumber utama perusahaan untuk memutuskan pembayaran dividen kepada investor adalah laba yang diperoleh, selain itu manajemen juga mempertimbangkan apakah menahan laba (tidak dibagikan kepada investor) untuk keperluan pembelian aktiva tetap guna meningkatkan operasional perusahaan yang berdampak pada meningkatnya kemampuan perusahaan dalam menghasilkan laba. Penelitian ini mengambil data laba bersih dan dividen kas perusahaan PT. Indofood CBT Sukses Makmur Tbk selama tujuh tahun yaitu mulai tahun 2014 sampai tahun 2020. Penelitian ini merupakan penelitian kuantitatif yang tergolong penelitian inferensial statistik parametris, meneliti mengenai pengaruh maka termasuk hipotesis asosiatif, menggunakan data rasio yaitu jenis data tertinggi dalam penelitian, kemudian menggunakan satu variabel independen dan satu variable dependen, sehingga alat analisis yang digunakan adalah analisis regresi sederhana. Hasil penelitian menunjukkan adanya pengaruh yang positif dan signifikan antara laba bersih dan dividen kas pada perusahaan PT Indofood CBP Sukses Makmur Tbk. Hal tersebut terlihat pada nilai signifikansi 0,02 < 0,05 dan T hitung sebesar 5,773 > nilai T tabel 2,570.
\end{abstract}

Kata Kunci: Laba, Dividen, Investor

\section{PENDAHULUAN}

Perusahaan secara umum di dalamnya terdapat banyak sumber daya yang terlibat untuk mencapai suatu tujuan yang telah ditetapkan sebelumnya. Tujuan tersebut adalah untuk meraih keuntungan yang besar melalui pengorbanan yang dilakukan, pengorbanan yang dimaksud yaitu berupa sumberdaya finansiaL sumberdaya manusia, waktu dan tenaga. Semua pihak internal mengupayakan agar perusahaan bisa memaksimalkan keuntungan dalam bentuk laba yang tinggi dan konsisten setiap tahunnya

Menurut Horngren, laba adalah penghasilan lebih dari total jumlah pendapatan dengan perbandingan total beban. Laba merupakan salah-satu faktor penentu perusahaan, apakah akan senantiasa beroperasi ataukah jatuh falid. Faktor yang mempengaruhi laba yaitu biaya, harga jual, dan volume penjualan dan produksi (Mulyadi, 2001: 513). 
Laba perusahaan terbentuk dari pendapatan yang dihasilkan perusahaan melalui kegiatan inti kemudian dikurangkan dengan beban-beban yang terjadi pada perusahaan tersebut. Selain pihak internal, terdapat pula pihak eksternal yang sangat mengingingkan perusahaan mendapatkan laba yaitu investor. Seorang investor pada saat menginvestasikan modalnya berharap mendapatkan keuntungan dari laba yang diperoleh perusahaan dalam bentuk dividen. Sulindawati et.al (2017: 132) dividen adalah pembagian keuntungan yang diberikan perusahaan dan berasal dari keuntungan yang dihasilkan perusahaan. Ungkapan yang sama oleh Rudianto (2012:290) "Dividen adalah bagian laba usaha yang diperoleh perusahaan dan diberikan oleh perusahaan kepada pemegang sahamnya sebagai imbalan atas kesediaan mereka menanamkan hartanya dalam perusahaan."

Laba yang tidak stabil akan mempengaruhi berbagai keputusan yang ada pada perusahaan, seperti manajemen akan mempertimbangkan apakah membagikan dividen kepada pemegang saham atau tidak. Alasan lainnya yaitu sebagai modal untuk melakukan penambahan aktiva tetap dalam mendukung operasional perusahaan.

Di sisi lainya, dividen merupakan salah satu motivasi investor untuk menanamkan dana di pasar modal (Yahya, 2005:2). Jadi investor sebelum melakukan investasi pada suatu perusahaan, tentu akan mempertimbangkan pembagian dividen pada perusahaan tersebut. Investasi adalah penanaman uang dengan harapan mendapat hasil dan nilai tambah (Webster, 1999).

Penelitian ini diharapkan memberikan tambahan ilmu pengetahuan di bidang ekonomi khususnya akuntansi yang berkitan dengan laba dan dividen. Penelitian ini bisa dijadikan referensi pertimbangan oleh investor sebelum melakukan investasi di perusahaan, dan juga sebagai pertimbangan oleh manajemen dalam memutuskan pembagian dividen kepada investor.

Investor berharap akan mendapatkan dividen berdasarkan modal yang telah ditanamkan di perusahaan, biasanya dividen dibagikan semisteran atau tahunan berdasarkan Rapat Umum Pemegang Saham (RUPS). Dividen pada umumnya dibagi menjadi 5 jenis yaitu Dividen Tunai, Dividen Saham, Dividen Properti, Dividen Skrip dan Dividen Likuidasi.

\section{PT Indofood CBP Sukses Makmur Tbk}

Indofood CBP Sukses Makmur Tbk (ICBP) didirikan 02 September 2009 dan mulai beroperasi secara komersial pada tahun 1 Oktober 2009. ICBP merupakan hasil pengalihan kegiatan usaha Divisi Mi Instan dan Divisi Penyedap Indofood Sukses Makmur Tbk (INDF), pemegang saham pengendali. Kantor pusat Indofood CBP berlokasi di Sudirman Plaza, Indofood Tower, Lantai 23, Jl. Jend. Sudirman, Kav. 76-78, Jakarta 12910, Indonesia, sedangkan pabrik perusahaan dan anak usaha berlokasi di pulau Jawa, Sumatera, Kalimatan, Sulawesi dan Malaysia. Perusahaan ini tergolong perusahaan yang sukses dikarenakan selalu mendapatkan pendapatan yang tinggi dan berdampak pada tingginya laba bersih yang diperoleh sehingga akan berdampak pada pembagian dividennya.

\section{Pengembangan Hipotesis}

Berdasarkan tinjauan teoritis di atas maka kerangka konseptual dan pengembangan hipotesis disajikan pada gambar 1 berikut ini:

\section{Gambar 1}

\section{Kerangka Konseptual Penelitian}

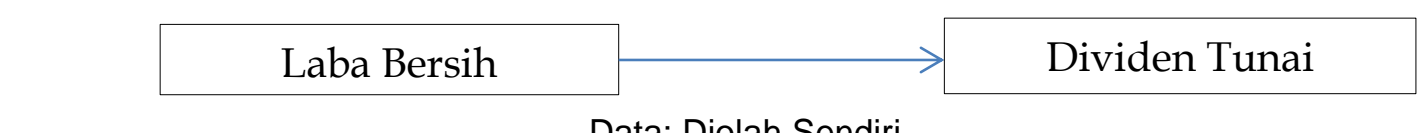

Hubungan Laba Bersih dengan Dividen

Data: Diolah Sendiri

(8). Penelitian yang dilakukan oleh Irawan dan Nurdhiana (2012) menyimpulkan bahwa Laba bersih yang diperoleh perusahaan berpengaruh positif dan signifikan terhadap kebijakan dividen. (1). Penelitian yang dilakukan Agung Dwi Cahyo (2013) bahwa laba bersih tidak berpengaruh signifikan terhadap kebijakan dividen perusahaan manufaktur yang terdaftar di BEI periode 2009-2012. Sehingga dapat diartikan bahwa laba bersih yang diperoleh 
perusahaan tidak berpengaruh terhadap kebijakan dividen yang diberikan perusahaan kepada para pemegang sahamnya.

Kemudian juga penelitian yang dilakukan oleh (2). Deisy Debora Wenas (2016) dengan judul penelitian "analisis pengaruh arus kas operasi dan laba bersih terhadap dividen kas pada perusahaan properti yang terdaftar di Bursa Efek Indonesia (BEI)" periode data yang diambil adalah tahun 2013-2015 sampel yang digunakan adalah 19 dari 49 jumlah populasi. Hasil penelitiannya adalah laba bersih secara parsial berpengaruh positif terhadap dividen kas.

(12). S Wicaksono \& M Nasir. 2014 "Pengaruh Profitabilitas, Likuiditas, Leverage, Pertumbuhan Perusahaan dan Ukuran Perusahaan terhadap Kebijakan Dividen pada Perusahaan Manufaktur yang Terdaftar di BEI Periode Tahun 2011-2013. Hasil penelitian Profitabilitas berpengaruh positif terhadap dividen, sedangkan likuiditas, leverage, dan ukuran perusahaan tidak berpengaruh, adapun pertumbuhan perusahaan berpengaruh negative terhadap dividen.

Tiocandra Riyando tahun 2015 melakukan penelitian dengan judul "Analisis Pengaruh Laba Bersih, Arus Kas Operasi, Pembayaran Dividen Kas Sebelumnya, dan Quick Ratio Terhadap Dividen Kas pada Perusahaan LQ-45 yang Terdaftar di Bursa Efek Indonesia Periode 20112013". Hasil penelitian, terdapat pengaruh laba terhadap dividen kas, namun tidak terdapat pengaruh laba terhadap arus kas operasi dan quick ratio terhadap dividen kas.

(6). Muhammad Fiqih tahun 2021 meneliti "Pengaruh Laba Bersih dan Arus Kas Operasi Terhadap Dividen Kas Pada Perusahaan Manufaktur Yang Terdaftar Di Bursa Efek Indonesia Periode 2015-2017". Jenis data kuantitatif yang berupa laporan keuangan perusahaan yang telah dipublikasikan, dengan populasi sebanyak 45 perusahaan. Hasil analisis dalam penelitian ini menunjukkan bahwa secara parsial laba bersih berpengaruh positif terhadap dividen kas dengan perolehan nilai thitung 3.203 lebih besar dari ttabel 2.018 dan tidak terdapat pengaruh arus kas operasi terhadap dividen kas dengan perolehan nilai thitung 1.811 lebih kecil dari ttabel 2.018. Sedangkan secara simultan atau bersama-sama laba bersih dan arus kas operasi memiliki pengaruh terhadap dividen kas dengan nilai Fhitung 38.884 lebih besar dari Ftabel 2.83 dengan tingkat Rsquare sebesar 0.649.

Berdasarkan uraian di atas maka peneliti melakukan penelitian dengan judul "Pengaruh Laba Bersih terhadap Pembayaran Dividen kas pada Perusahaan PT Indofood CBP Sukses Makmur Tbk".

H0: Penelitian ini adalah tidak terdapat pengaruh yang signifikan antara laba bersih dengan pembayaran dividen di perusahaan PT Indofood CBP Sukses Makmur Tbk

$\mathrm{H} 1$ : Penelitian ini terdapat pengaruh yang signifikan antara laba bersih dengan dividen pada di perusahaan PT Indofood CBP Sukses Makmur Tbk RQ: Apakah terdapat pengaruh yang signifikan antara laba bersih dengan dividen di perusahaan PT Indofood CBP Sukses Makmur Tbk.

\section{METODE PENELITIAN}

Jenis penelitian yang digunakan adalah penelitian kuantitatif statistik inferensial, penelitian ini tergolong parametris menggunakan hipotesis asosiatif untuk melihat pengaruh variabel independen dan variabel dependen. Populasi adalah wilayah generalisasi yang terdiri atas objek/subjek yang mempunyai kualitas dan karakteristik yang ditetapkan oleh peneliti untuk dipelajari dan kemudian ditarik kesimpulannya (Sugiyono, 2014:80). Populasi sekaligus sampel pada penelitian ini adalah PT Indofood CBP Sukses Makmur Tbk.

Seperti yang telah dikemukkan bahwa penelitian ini adalah penelitian dengan menggunakan hipotesis asosiatif sehingga analisis data yang digunakan adalah regresi sederhana, penggunaan regresi sederhana diantaranya karena data yang digunakan adalah data rasio yaitu data laba bersih dan pembayaran dividen perusahaan selama tujuh tahun (2014-2020). Data diperoleh dari bursa efek Indonesia melalui situs www.idx.co.id dan www.idnfinancials.com. 
Berikut tabel informasi mengenai tahun, laba bersih, dan dividen kas yang dibagikan oleh PT Indofood CBP Sukses Makmur Tbk. Pengukuran mata uang menggunakan Rupiah (triliun).

Tabel 1: Sampel yang digunakan

\begin{tabular}{|l|l|l|}
\hline Tahun & Laba Bersih $(\mathbf{X})$ & Dividen Kas $(\mathbf{Y})$ \\
\hline 2014 & 2.574 .172 & 1.294 .472 \\
\hline 2015 & 2.923 .148 & 1.107 .882 \\
\hline 2016 & 3.631 .301 & 1.492 .724 \\
\hline 2017 & 3.543 .173 & 1.795 .934 \\
\hline 2018 & 4.658 .781 & 1.889 .229 \\
\hline 2019 & 5.360 .029 & 2.274 .072 \\
\hline 2020 & 7.418 .574 & 2.507 .310 \\
\hline
\end{tabular}

Sumber Data: https://www.idxchannel.com/ dan www.idnfinancials.com/

Berdasarkan tabel di atas, laba perusahaan PT Indofood CBP Sukses Makmur Tbk selalu mengalami kenaikan yang sangat signifikan sejak tahun 2014 sampai tahun 2020. Tentu kenaikan laba tersebut dipengaruhi oleh kenaikan pendapatan yang diperoleh PT Indofood CBP Sukses Makmur Tbk dari tahun ke tahun juga mengalami peningkatan. Mulai tahun 2014-2020 PT Indofood CBP Sukses Makmur Tbk mengalami kenaikan laba sebesar 288\%.

Tabel 1 juga memberikan informasi bahwa dividen yang dibayarkan oleh manajemen kepada investor terus-menerus mengalami kenaikan, kecuali pada tahun 2015 yang mengalami penurunan, namun penurunannya tidak begitu signifikan hanya menurun sekitar $14 \%$ dari tahun 2014. Jika dihitung maka dari tahun 2014 sampai tahun 2020 pembagian dividen PT Indofood CBP Sukses Makmur Tbk meningkat sekitar 194\%.

Uji statistik pada penelitian ini dimulai dengan uji normalitas, linearitas. Selanjutnya dilanjutkan dengan uji heterokedastisitas dan regresi sederhana. uji normalitas adalah metode pengujian statistika yang digunakan untuk menilai sebaran data pada sampel kelompok data (variabel) apakah terdistribusi normal ataukah tidak.

Uji normalitas memiliki fungsi sebagai media uji dalam menentukan apakah model regresi, variabel pengganggu maupun residual terdistribusi normal ataukah tidak. Sugiyono dan Susanto (2015:323) uji linearitas dapat dipakai untuk mengetahui apakah variabel terikat dengan variabel bebas memiliki hubungan linear atau tidak secara signifikan. Uji linearitas dapat dilakukan melalui test of linearity.

Uji Heterokedastisitas bertujuan untuk menguji apakah dalam model regresi terjadi ketidaksamaan varian dari residual satu pengamatan ke pengamatan yang lain. Jika varian dari residual satu pengamatan ke pengamatan yang lain tetap, maka disebut homoskedastisitas dan jika berbeda akan disebut heteroskedastisitas. Data yang baik yaitu tidak terjadi heterokedastisitas.

Analisis regresi sederhana bertujuan untuk mengetahui pengaruh dari suatu variabel terhadap variabel lainnya. Pada analisis regresi suatu variabel yang mempengaruhi disebut variabel bebas atau independent variable, sedangkan variabel yang dipengaruhi disebut variabel terkait atau dependent variable. Jika persamaan regresi hanya terdapat satu variabel bebas dengan satu variabel terkait, maka disebut dengan persamaan regresi sederhana. Jika variabel bebasnya lebih dari satu, maka disebut dengan persamaan regresi berganda. Pada regresi sederhana kita dapat mengetahui berapa besar perubahan dari variabel bebas dapat mempengaruhi suatu variabel terkait.

Variabel yang mempengaruhi disebut dengan berbagai istilah: variabel independen, variabel bebas, variabel penjelas, variabel eksplanatorik, atau variabel $X$ karena dalam grafik sering digambar sebagai absis atau sumbu $\mathrm{X}$ ). Variabel yang dipengaruhi dikenal sebagai variabel dependen, variabel terikat, atau variabel Y. Kedua variabel ini dapat merupakan variabel acak (random), namun variabel yang dipengaruhi harus selalu variabel acak. Analisis regresi adalah salah satu analisis yang luas pemakaiannya. Analisis regresi digunakan untuk melakukan prediksi dan ramalan. 
Analisis regresi linier sederhana adalah hubungan secara linear antara satu variabel independen $(\mathrm{X})$ dengan variabel dependen $(\mathrm{Y})$. Analisis regresi sederhana dapat digunakan untuk mengetahui arah dari hubungan antara variabel bebas dengan variabel terikat, apakah memiliki hubungan positif atau negatif serta untuk memprediksi nilai dari variabel terikat apabila nilai variabel bebas mengalami kenaikan ataupun penurunan.

Rumus regresi linear sederhana sebagai berikut:

$Y=a+b X$

Keterangan:

$Y \quad=$ Variabel dependen (variabel terikat)

$\mathrm{X}=$ Variabel independent (variabel bebas)

a $\quad=$ Konstanta (nilai dari $Y$ apabila $X=0$ )

$\mathrm{b}=$ Koefisien regresi (pengaruh positif atau negatif)

\section{HASIL DAN PEMBAHASAN}

Sebelum uji regresi dilakukan, sebagaimana yang telah dikemukakan pada bab tiga, terlebih dahulu dilakukan uji normalitas data. Uji normalitas data memiliki tujuan apakah data yang dimiliki adalah berdistribusi normal sebagai syarat dari uji regresi. Ketentuan dari uji normalitas data yaitu ketentuan nilai signifikansi harus $>0,05$. Pengujian normalitas data dapat dilakukan dengan menggunakan dua metode pertama Kolmogorov-Smirnov dan Shapiro Wilk. Meskipun ada yang berpendapat, jika sampel di bawah 50, maka yang dipakai Shapiro Wilk, dan jika sampel $\leq 50$ maka memakai Smirnov. Namun pada penelitian ini menyajikan kedua alat ukur tersebut.

Tabel 2 Uji Normalitas Data Tests of Normality

\begin{tabular}{ll|l|l|l|l|l}
\multicolumn{8}{c}{$\begin{array}{l}\text { Kolmogorov-Smirnova } \\
\text { Statistic }\end{array}$} & df & Sig. & Shapiro-Wilk & Statistic & df & Sig. \\
\hline Laba & .227 & 7 & $.200^{*}$ & .908 & 7 & .383 \\
\hline Dividen & .133 & 7 & $.200^{*}$ & .965 & 7 & .863 \\
\hline
\end{tabular}

${ }^{\star}$. This is a lower bound of the true significance.

a. Lilliefors Significance Correction

Sumber: Data diolah menggunakan SPSS 25

Tabel di atas menunjukkan nilai dari Kolmogorov-Smirnov dan Shapiro Wilk. Nilai signifikansi Kolmogorov-Smirnov adalah 0,200 yang berarti $>0,05$. Begitupun nilai signifikansi dari Shapiro Wilk yaitu 0,383 dan 0,863 menunjukkan data penelitian sudah berdistribusi normal.

Alat ukur lainya dalam uji normalitas data yaitu mengamati gambar P-P Plot dengan ketentuan jika data berada di sekitar garis P-P Plot maka data adalah normal.

\section{Gambar 2 P-P Plot}

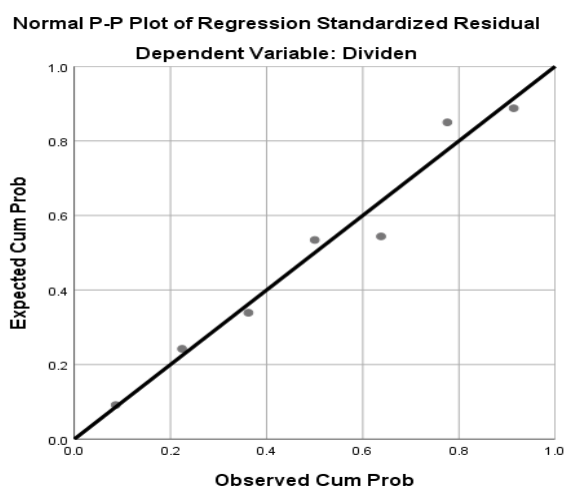

Sumber: Data diolah menggunakan SPSS 25

Gambar P-P Plot menyajikan bahwa semua data berada disekitar garis dan mengikuti garis tersebut, maka data berdistribusi normal dan memenuhi syarat untuk pengujian selanjutnya. 
Uji linearitas dilakukan untuk melihat linearitas data atau kesesuaian data. Dikatakan linear jika nilai signifikansi $>0,05$. atau membandingkan nilai $F$ hitung dengan $F$ tabel. Jika $F$ hitung $>F$ tabel maka data linear.

\section{Tabel 3 Uji Linearitas ANOVA Table}

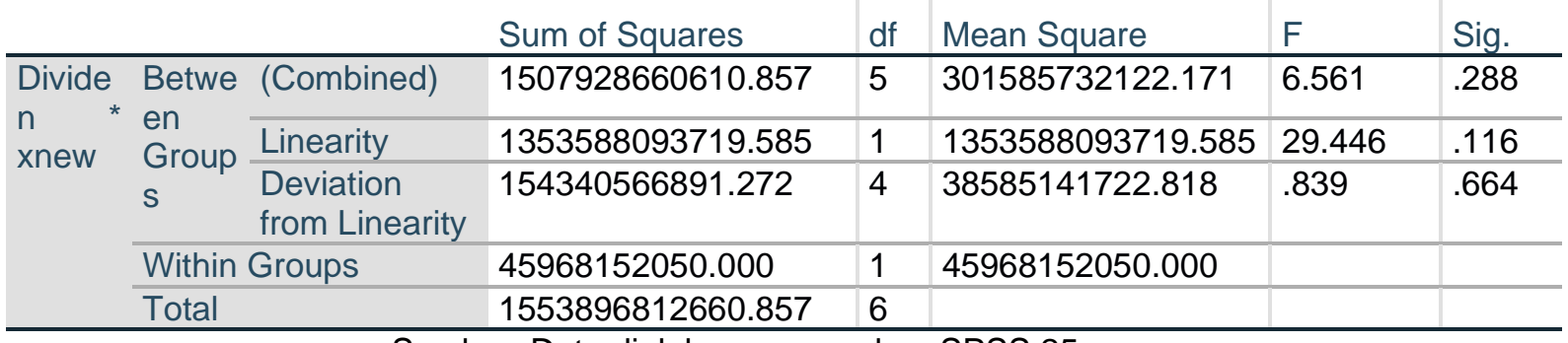

Sumber: Data diolah menggunakan SPSS 25

Nilai signifikansi dari tabel di atas yaitu $0,664>0,05$ berarti data linear, selain itu data dapat pula diamati dengan membandingkan $\mathrm{F}$ hitung dengan $\mathrm{F}$ tabel. Setelah dilakukan perhitungan sesuai dengan penelitian ini maka didapatkan nilai $F$ tabel $5,99<0,839 F$ hitung, artinya $F$ hitung $>\mathrm{F}$ tabel, memperkuat bahwa data bersifat linear.

Heterokedastisitas adalah kebalikan dari ho,oskedastisitas, yaitu keadaan dimana terjadinya ketidaksamaan varian dari error untuk semua pengamatan setiap variabel bebas pada model regresi. Uji Heterokedastisitas (ketidaksamaan varians), data yang baik yaitu tidak terjadi heterokedastisitas cara menentukan:

1. Mengamati gambar Sceterplot, yaitu ketika titik menyebar dan tidak membentuk pola tertentu maka tidak terjadi heterokedastisitas.

2. Mengamati nilai signifikansi pada tabel uji Glejser, jika nilai tersebut $>0,05$, maka tidak terjadi heterokedastisitas.

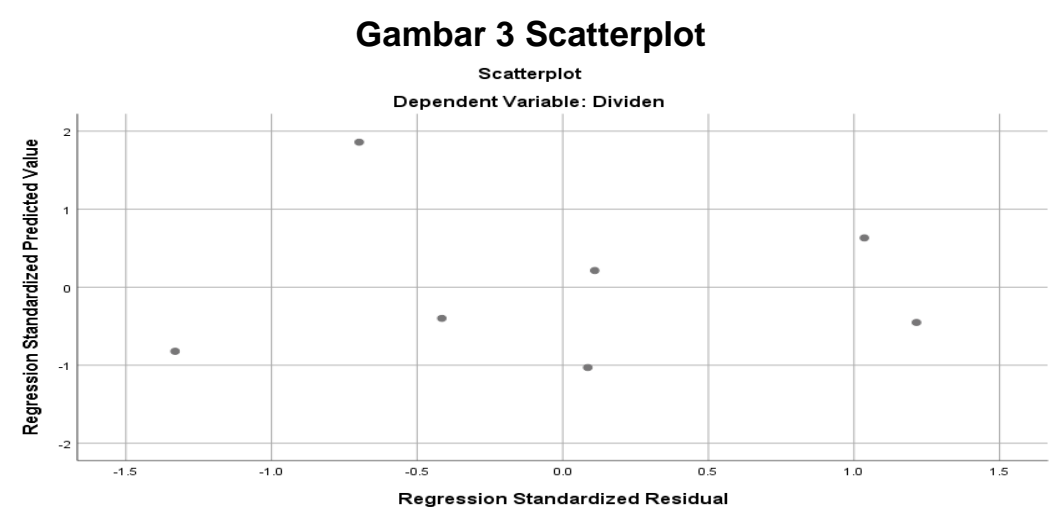

Sumber: Data diolah menggunakan SPSS 25

Gambar di atas yaitu titik menyebar dan tidak membentuk pola tertentu maka tidak terjadi heterokedastisitas. Pola yang dimaksud adalah adanya bentuk garis yang sejajar ataupun tidak sejajar tetapi membentuk pola seperti berbentuk gelombang dan semisalnya. Alat ukur lainnya yaitu uji Glejser.

\begin{tabular}{|c|c|c|c|c|c|c|}
\hline \multirow[b]{3}{*}{ Model } & \multicolumn{6}{|c|}{$\begin{array}{c}\text { Tabel } 3 \text { Uji Glejser } \\
\text { Coefficients }^{\mathrm{a}}\end{array}$} \\
\hline & & Unstandardi & ed Coefficients & $\begin{array}{l}\text { Standardized } \\
\text { Coefficients }\end{array}$ & & \\
\hline & & B & Std. Error & Beta & $t$ & Sig. \\
\hline \multirow[t]{2}{*}{1} & (Constant) & 133859.682 & 126060.947 & & 1.062 & .337 \\
\hline & Laba & .002 & .028 & .026 & .058 & .956 \\
\hline
\end{tabular}

a. Dependent Variable: Abs_Res

Sumber: Data diolah menggunakan SPSS 25 
Berdasarkan ketentuan yang telah dikemukakan bahwa, jika nilai tersebut $>0,05$, maka tidak terjadi heterokedastisitas. Nilai signifikansi yaitu sebesar $0,956>0,05$ menunjukkan tidak adanya heterokedastisits, maka data memenuhi syarat untuk dilakukan uji regresi.

Uji Regresi dilakukan untuk menguji apakah terdapat pengaruh yang signifikan antara variabel independen (laba bersih) dengan variabel dependen (dividen kas). Sebelun interpretasi dari uji regresi dilakukan maka terlebih dahulu dilakukan interpretasi pada tabel Model Summary dan interpretasi persamaan regresi. Dikarenakan model summary menjelaskan hubungan antara variabel independen (laba bersih) dan variabel dependen (dividen kas), demikian juga persamaan regresi yaitu menjelaskan nilai konstan dan hubungan kedua variabel tersebut.

\begin{tabular}{|c|c|c|c|c|c|}
\hline \multirow[b]{2}{*}{ Model } & \multicolumn{4}{|c|}{$\begin{array}{l}\text { Tabel } 4 \text { Model Summary } \\
\text { Model Summary }\end{array}$} & \multirow[b]{2}{*}{$\begin{array}{l}\text { Std. Error o } \\
\text { the Estimate }\end{array}$} \\
\hline & $\mathrm{R}$ & R Square & $\begin{array}{l}\text { Adjuste } \\
\text { Square }\end{array}$ & $\mathrm{R}$ & \\
\hline 1 & $.932^{\mathrm{a}}$ & .870 & .843 & & 201362.207 \\
\hline
\end{tabular}

a. Predictors: (Constant), Laba

b. Dependent Variable: Dividen

Sumber: Data diolah menggunakan SPSS 25

Interpretasi dari tabel di atas adalah nilai $\mathrm{R}$ menunjukkan terdapat hubungan (korelasi) antara variabel $x$ dan y dengan nilai 0,471 , sedangkan nilai $R$ Square adalah 0,843 atau $84,3 \%$ yaitu variabel $x$ atau laba bersih (independen/bebas) dapat mempengaruhi variabel y atau dividen kas (dependen/terikat) sebesar $84,3 \%$ sisanya $15,7 \%$ dipengaruhi oleh variabel lain yang tidak menjadi variabel pada penelitian ini.

Persamaan regresi sederhana dapat dihitung dengan rumus $Y=a+b X$.

Keterangan:

$\mathrm{Y}=$ Variabel dependen (variabel terikat)

$\mathrm{X}=$ Variabel independent (variabel bebas)

a $\quad$ Konstanta (nilai dari $\mathrm{Y}$ apabila $\mathrm{X}=0$ )

$\mathrm{b} \quad=$ Koefisien regresi (pengaruh positif atau negatif)

\begin{tabular}{|c|c|c|c|c|c|c|}
\hline \multicolumn{7}{|c|}{$\begin{array}{c}\text { Tabel } 5 \text { Koefisien Regresi } \\
\text { Coefficients }^{\mathrm{a}}\end{array}$} \\
\hline \multirow{2}{*}{\multicolumn{2}{|c|}{ Model }} & \multicolumn{2}{|c|}{ Unstandardized Coefficients } & \multirow{2}{*}{$\begin{array}{l}\text { Standardized } \\
\text { Coefficients } \\
\text { Beta }\end{array}$} & \multirow[b]{2}{*}{$\mathrm{t}$} & \multirow[b]{2}{*}{ Sig. } \\
\hline & & B & Std. Error & & & \\
\hline 1 & (Constant) & 548720.397 & 224175.233 & & 2.448 & .058 \\
\hline & Laba & .283 & .049 & .932 & 5.773 & .002 \\
\hline
\end{tabular}

a. Dependent Variable: Dividen

Sumber: Data diolah menggunakan SPSS 25

Dari tabel di atas menunjukkan bahwa:

1. Persamaan regresi $Y=548720.397 \beta+0,283$, artinya Kontanta sama dengan 548720.397 yaitu jika Variabel $x$ (independen) $=0$ maka variabel y (dependen) $=548720.397$.

2. Koefisien $x=0,283$ yaitu jika variabel $x$ naik 1 (satu) maka variabel y mengalami kenaikan 0,283 Terakhir adalah uji regresi sederhana yaitu menguji ada-tidaknya pengaruh antara variabelx dan variabel y, Ketentuannya:

1. Mengamati nilai sig yaitu jika nilai sig $<0,05$ maka terdapat pengaruh yang signifikan anatara variabel $x$ dan $y$.

2. Bandingkan Nilai $T$ Hitung dengan $T$ Tabel. Jika $T$ Hitung $>\mathrm{T}$ Tabel maka terdapat pengaruh.

\begin{tabular}{|c|c|c|c|c|c|c|}
\hline \multicolumn{7}{|c|}{$\begin{array}{c}\text { Tabel } 6 \text { kefisien regresi } \\
\text { Coefficients }^{\mathrm{a}}\end{array}$} \\
\hline Model & & $\begin{array}{l}\text { Unstandardiz } \\
\text { B }\end{array}$ & $\begin{array}{l}\text { d Coefficients } \\
\text { Std. Error }\end{array}$ & $\begin{array}{l}\text { Standardized } \\
\text { Coefficients } \\
\text { Beta }\end{array}$ & $t$ & Sia \\
\hline 1 & (Constant) & 548720.397 & 224175.233 & & 2.448 & .058 \\
\hline
\end{tabular}




\begin{tabular}{l|l|l|l|l|l}
\hline Laba & .283 & .049 & .932 & 5.773 & .002 \\
\hline
\end{tabular}

a. Dependent Variable: Dividen

Sumber: Data diolah menggunakan SPSS 25

Berdasarkan uji regresi pada tabel di atas maka nilai signifikansi $0,02<0,05$ menandakan ada pengaruh yang signifikan antara variabel independen yakni laba bersih dengan variabel dependen yakni dividen kas. Interpretasi lainnya yaitu dengan membandingkan $\mathrm{T}$ hitung dengan T tabel, berdasarkan perhitungan yang dilakukan nilai T tabel 2.570. maka nilai T hitung sebesar 5,773 > nilai $T$ tabel 2,570. Berarti terdapat pengaruh yang positif dan signifikan antara variabel independen yakni laba bersih dengan variabel dependen yakni dividen kas. Maka HO ditolak dan $\mathrm{H} 1$ diterima.

Hasil penelitian ini telah sesuai dengan teori yang telah dikemukakan bahwa Sulindawati et.al (2017: 132) dividen adalah pembagian keuntungan yang diberikan perusahaan dan berasal dari keuntungan yang dihasilkan perusahaan. Ungkapan yang sama oleh Rudianto (2012:290) "Dividen adalah bagian laba usaha yang diperoleh perusahaan dan diberikan oleh perusahaan kepada pemegang sahamnya sebagai imbalan atas kesediaan mereka menanamkan hartanya dalam perusahaan."

Penelitian ini juga sesuai dengan penelitian yang telah dilakukan oleh Irawan dan Nurdhiana (2012) dan Deisy Debora Wenas (2016) menyimpulkan bahwa Laba bersih yang diperoleh perusahaan berpengaruh positif dan signifikan terhadap kebijakan dividen. Perusahaan yang terus-menerus mengalami pertumbuhan laba maka investor akan mendapatkan keuntungan, berbeda dengan perusahaan yang mengalami laba yang tidak menentu, artinya kadang keuntungan kemudian kadang pula mengalami kerugian, perusahaan semacam ini akan sulit mensejahterakan investornya dikarenakan peluan pembagian dividen adalah sangat kecil, apalagi jika perusahaan terus-menerus mengalami kerugian, maka sudah hampir bisa dipastikan pembayaran dividen tidak akan dilakukan. Berbeda dengan PT Indofood CBP Sukses Makmur Tbk, perusahaan ini terus-menerus mengalami kenaikan laba bersih sejak tahun 2014 sampai tahun 2020 (sesuai data pada penelitian ini), sehingga berdampak pada kenaikan pembagian dividen kepada investor.

\section{KESIMPULAN}

Seperti yang telah dijelaskan sebelumnya, penelitian menggunakan data dari perusahaan PT Indofood CBP Sukses Makmur Tbk mulai tahun 2014-2020 (tujuh tahun). Penelitian ini merupakan penelitian kuantitatif yang tergolong penelitian inferensial statistik parametris, meneliti mengenai pengaruh maka termasuk hipotesis asosiatif, menggunakan data rasio yaitu jenis data tertinggi dalam penelitian, kemudian menggunakan satu variabel independen dan satu variable dependen, sehingga alat analisis yang digunakan adalah analisis regresi sederhana.

Hasil penelitian menunjukkan adanya pengaruh yang positif dan signifikan antara laba bersih dan dividen kas pada perusahaan PT Indofood CBP Sukses Makmur Tbk. Hal tersebut terlihat pada nilai signifikansi $0,02<0,05$. Cara lainnya dengan membandingkan $T$ hitung dengan $T$ tabel, berdasarkan perhitungan yang dilakukan nilai T tabel 2.570. maka nilai T hitung sebesar $5,773>$ nilai T tabel 2,570. Berarti terdapat pengaruh yang positif dan signifikan antara variabel independen yakni laba bersih dengan variabel dependen yakni dividen kas.

Kelemahan dari penelitian ini adalah hanya menggunakan satu variabel independen yaitu laba bersih, padahal masih banyak variabel lain yang kemungkinan memiliki pengaruh terhadap dividen kas dan menarik untuk diteliti. Penelitian juga terbatas pada satu perusahaan saja yaitu PT Indofood CBP Sukses Makmur Tbk, maka disarankan bagi peneliti selanjutnya melakukan penelitian dengan objek yang lebih luas seperti perusahaan jasa, manufaktur, perusahaan dagang dengan menggunakan sampel yang proporsional dan representatif.

\section{REFERENCES}

[1] Agung Dwi Cahyo. 2013. Pengaruh laba bersih, arus kas operasi, investment opportunity set terhadap kebijakan dividen perusahaan manufaktur periode 2009- 2012. Jurnal FE Universitas Maritim Raja Ali Haji Tanjungpinang.

[2] Deisy Debora Wenas. 2016. Analisis Pengaruh Arus Kas Operasi dan Laba Bersih Terhadap Dividen Kas Pada Perusahaan Properti yang Terdaftar Di Bursa Efek Indonesia. Jurnal Emba, Volume 5, No 1, Tahun 2017. 
[3] Gumanti, Tatang Ary. 2013. Kebijakan Dividen Teori, Empiris, dan Implikasi. Jakarta: UPP STIM YKPN.

[4] Harrison, Walter T., Charles T. Horngren., C. William Thomas ,.Themin Suwardy. 2012. (Alih Bahasa oleh Gina Gania). Financial Accounting Jilid 1. Jakarta: Erlangga.

[5] Jen Surya (2010) "Pengaruh Laba, Arus Kas Operasi, dan Arus Kas Bebas Terhadap Dividen Kas pada Perusahaan Manufaktur yang Terdaftar di BEI”. Jurnal Investasi volume 6. No 2:111-123.

[6] Muhammad Fiqih. 2021. Pengaruh Laba Bersih dan Arus Kas Operasi Terhadap Dividen Kas Pada Perusahaan Manufaktur Yang Terdaftar Di Bursa Efek Indonesia Periode 2015-2017. Jurnal Akuntansi Mahasiswa Unsurya. Volume 1. No1.

[7] Mulyadi. 2001. Sistem Akuntansi Edisi Tiga. Jakarta : Salemba Empat.

[8] Nurdhiana, Irawan. 2010. Pengaruh Laba Bersih dan Arus Kas Operasi Terhadap Kebijakan Dividen Pada Perusahaan Di BEI.

[9] Rudianto, 2012, Pengantar Akuntansi Konsep \& Teknik Penyusunan Laporan Keuangan, Penerbit : Erlangga, Jakarta.

[10] Scroeder, Richard G. dan Myrtle Clark (1998). Accounting Theory-Text and Reading. 6th Edition. Canada : John Willey \& Sons, Inc.

[11] Sulindawati, Ni Luh Gede Erni, Gede Adi Yuniarta dan I Gusti Ayu Purnamawati. 2017. Manajemen Keuangan : Sebagai Dasar Pengambilan Keputusan Bisnis. Depok : Rajawali Pers.

[12] S Wicaksono \& M Nasir. 2014 "Pengaruh Profitabilitas, Likuiditas, Leverage, Pertumbuhan Perusahaan dan Ukuran Perusahaan terhadap Kebijakan Dividen pada Perusahaan Manufaktur yang Terdaftar di BEI Periode Tahun 2011-2013. Journal Of Accounting Volume 3, Nomor 4, Tahun 2014, Halaman 1-13

[13] Tiocandra Riyando. 2015. Analisis Pengaruh Laba Bersih, Arus Kas Operasi, Pembayaran Dividen Kas Sebelumnya, dan Quick Ratio Terhadap Dividen Kas pada Perusahaan LQ-45 yang Terdaftar di Bursa Efek Indonesia Periode 2011-2013. Jurnal. Faculty of Economy Riau University, Pekanbaru.

[14] Wallace, Wanda A. (1997). Financial Accounting. 3rd ed. Cincinati : South Western Publishing.

[15] Webster, Federick., 1999. Behavioral Customer In Marketing Relationship. 3th Edition. Princetown University Press.

[16] Yahya, Muhammad Nur (2005) "Tingkat Keuntungan Dan Likuiditas Saham Disekitar IPO Dengan Ukuran Perusahaan Sebagai Variabel Kontrol". Tesis, Universitas Syiah Kuala.

[17] https://www.idxchannel.com/ (diakses tanggal 12 Oktober 2021).

[18] www.idnfinancials.com/ (diakses tanggal 12 Oktober 2021). 